\title{
HUBUNGAN TINGKAT PENGETAHUAN DIET DAN AKTIVITAS FISIK TERHADAP STATUS GIZI PADA SISWA SEKOLAH MENENGAH ATAS
}

\author{
Fuadi Raja Baja ${ }^{1}$, Cerika Rismayanthi ${ }^{1}$ \\ ${ }^{1}$ Ilmu Keolahragaan, Fakultas Ilmu Keolahragaan, Universitas Negeri Yogyakarta, Jl. Colombo No. 1, \\ Karangmalang, Depok, Sleman, Daerah Istimewa Yogyakarta, Indonesia \\ fuadiraja.2019@student.uny.ac.id,cerika@uny.ac.id
}

\begin{abstract}
Abstrak
Penelitian ini dilatar belakangi oleh banyaknya remaja yang belum mengetahui pemilihan nutrisi yang baik dan menganggap konsep diet hanya untuk menurunkan berat badan serta kebiasaan pola aktivitas fisik pasif atau sedentari pada remaja. Jenis penelitian yang digunakan adalah penelitian deskriptif dengan pendekatan cross sectional. Sampel dalam penelitian ini adalah 45 siswa SMAN 1 Yogyakarta. Variabel yang diteliti yaitu pengetahuan diet, aktivitas fisik dan status gizi. Instrumen yang digunakan untuk mengukur pengetahuan diet adalah dengan tes tingkat pengetahuan yang telah tervalidasi, aktivitas fisik dengan menggunakan Global Physical Activity Questonnaire(GPAQ) dan status gizi dengan indeks massa tubuh. Status gizi digolongkan menjadi status gizi baik dan tidak baik. Pengolahan data dianalisis secara deskriptif. Hubungan pengetahuan diet dan aktivitas fisik terhadap status gizi dengan metode Chi Square dan Goodman Kruskall - Gamma Statistic. Hasil penelitian menunjukkan ada hubungan antara pengetahuan diet terhadap status gizi pada siswa SMAN 1 Yogyakarta $(\mathrm{r}=0,62$ : $\mathrm{p}=0,01)$ serta ada hubungan antara aktivitas fisik terhadap status gizi pada siswa SMAN 1 Yogyakarta $(\mathrm{r}=0,85 ; \mathrm{p}=0,000)$. Dapat disimpulkan bahwa semakin tinggi tingkat pengetahuan diet dan aktivitas fisik siswa maka akan semakin baik status gizinya.
\end{abstract}

Kata kunci: Pengetahuen Diet, Aktivitas Fisik, Status Gizi

\section{RELATIONSHIP OF DIET KNOWLEDGE LEVELS AND PHYSICAL ACTIVITIES TOWARD NUTRITIONAL STATUS IN MIDDLE SCHOOL STUDENT}

\begin{abstract}
This research is motivated by the many teenagers who do not know the selection of good nutrition and consider the concept of diet only to lose weight and habitual patterns of passive or sedentary physical activity in adolescents. This type of research is a descriptive study with cross sectional approach. The sample in this study were 45 students of SMAN 1 Yogyakarta. The variables studied were dietary knowledge, physical activity and nutritional status. The instrument used to measure dietary knowledge is to test the level of knowledge that has been validated, physical activity using the Global Physical Activity Questonnaire (GPAQ) and nutritional status with body mass index. Nutritional status is classified as good and bad nutritional status. Data processing was analyzed descriptively. The relationship of dietary knowledge and physical activity to nutritional status with the Chi Square method and Goodman Kruskall - Gamma Statistics. The results showed that there was a relationship between dietary knowledge and nutritional status in students of SMAN 1 Yogyakarta $(r=0.62: p=0.01)$ and there was a relationship between physical activity and nutritional status in students of SMAN 1 Yogyakarta $(r=0.85 ; p=0,000)$. It can be concluded that the higher the level of dietary knowledge and physical activity of students, the better the nutritional status.
\end{abstract}

Keywords: Diet Recognition, Physical Activity, Nutritional Status 


\section{PENDAHULUAN}

Kehidupan manusia saat ini telah memasuki keadaan yang sangat kompleks, berbagai aktivitas serta berbagai permasalahan harus dihadapi, yang tentunya akan menguras banyak energi baik secara fisik maupun psikis. Kondisi seperti ini tentunya menuntut seseorang untuk memiliki kondisi fisik dan mental yang sangat kuat. Manusia memiliki fase remaja yang merupakan dekade kedua dalam masa kehidupan. Fase remaja merupakan suatu fase perkembangan yang dinamis dalam kehidupan seseorang. Perkembangan yang terjadi pada individu relatif pesat. Dalam fase inilah terjadi periode transisi dari masa kanak ke dewasa. Berbagai perubahan menunjukkan tanda-tandanya, mulai dari pertumbuhan fisik yang relatif cepat, mental, emosional, bahkan sosial (Ida Mardalena, 2017: 94).

Fase remaja merupakan masa dimana anak sekolah remaja biasanya mengalami perubahan gaya hidup dan kebiasaan makan. Adanya keinginan untuk mengembangkan body image, terutama pada anak perempuan sangat memengaruhi pola makannya. Pada fase remaja, khususnya anak sekolah sering mengalami masalah kesehatan dan gizi, masalah yang terkait dengan status gizinya maupun pola makan yang akan berdampak pada kesehatannya. Masalah status gizi pada anak sekolah biasanya adalah masalah pendek, kurus, dan gemuk. Selain itu anak sekolah juga mengalami masalah pada pemilihan makanan jajanan yang tidak tepat (Dyah Umiyarni, 2018: 5).

Banyak masalah yang terjadi terhadap remaja karena pemilihan kebutuhan gizi atau nutrisi yang kurang tepat. Masalah yang sering terjadi terhadap anak sekolah meliputi kurus dan sangat kurus, pendek dan sangat pendek, serta gemuk dan obesitas. Adapun prevalensi kurus di Indonesia berdasar Riskesdas (2013) pada remaja anak sekolah umur 16 - 18 tahun adalah 9,4\% (1,9\% sangat kurus dan 7,5\% kurus). Sebanyak 11 provinsi dengan prevalensi kurus diatas nasional. Salah satunya provinsi Daerah Istimewa Yogyakarta dengan nilai diatas $8 \%$. Status kurus yang terjadi pada remaja dapat berdampak terhadap pertumbuhan dan perkembangan pada remaja.

Pertumbuhan pada fase remaja sangat penting, pada masa ini remaja mulai mengalami pertumbuhan fisik yang relatif cepat. Salah satu pemilihan nutrisi atau kebutuhan gizi juga mempengaruhi pertumbuhan pada remaja. masalah yang terjadi pada remaja adalah pendek, pendek menunjukan kekurangan gizi kronis. Secara nasional prevalensi pendek pada anak sekolah umur 16 -18 tahun adalah 31,4\% (7,5\% sangat pendek dan 23,9\% pendek). Sebanyak 17 provinsi dengan prevalensi pendek di atas prevalensi nasional. Masalah lain yang terjadi pada remaja atau anak sekolah yaitu gemuk dan obesitas Berdasarkan data Riskesdas (2013), prevalensi gemuk pada remaja umur 16-18 tahun sebanyak 7,3\% (5,7\% gemuk dan 1,6\% obesitas) dengan provinsi Daerah Istimewa Yogyakarta dengan nilai diatas 2,0\%. Hal ini tentunya bisa meningkat dengan melihat gaya hidup remaja atau anak sekolah di masa sekarang. Penelitian yang dilakukan oleh Collins et al (2008) menemukan faktor-faktor yang menjadi penyebab kegemukan anak di Indonesia, salah satunya adalah pemilihan makanan yang selalu cepat saji atau junkfood.

Dari beberapa masalah diatas diet merupakan salah satu upaya untuk menerapkan pola hidup sehat, harus dilaksanakan secara tepat oleh pelakunya, agar tujuan yang diinginkan tercapai dengan optimal. Dalam kamus Gizi Pelengkap Kesehatan Keluarga 2009 keluaran Persatuan Ahli Gizi Indonesia (Persagi), Diet memiliki arti sebagai pengaturan pola dan konsumsi makanan serta minuman yang dilarang, dibatasi jumlahnya, dimodifikasi, atau diperolehkan dengan jumlah tertentu untuk tujuan terapi penyakit yang diderita, kesehatan, atau penurunan berat badan. Dengan memahami konsep diet secara tepat, tentunya diet akan menjadi hal yang menyenangkan untuk dilakukan. Anggapan salah lainnya adalah tentang pengertian diet, beberapa orang beranggapan bahwa diet adalah suatu upaya yang semata-mata hanya untuk menurunkan berat badan dengan cara mengurangi porsi makan maupun frekuensi makan, sedangkan pengertian sebenarnya diet secara umum merupakan prasarat bagi 
kesehatan, sebagai usaha memajukan kualitas hidup, atau kesejahteraan, dan pencegahan terhadap penyakit terkait gizi, yaitu dengan mengatur asupan nutrisi yang dibutuhkan tubuh (Mary E. Barasi, 2007: 6).

\section{METODE}

Penelitian ini adalah penelitian yang bersifat korelasi atau hubungan. Penelitian ini digunakan untuk mengetahui tingkat hubungan antara dua variabel atau lebih, tanpa melakukan perubahan atau manipulasi terhadap data yang memang sudah ada (Suharsimi Arikunto dalam Nur Robiah, 2016: 45). Menurut Suharsimi Arikunto (2010: 313) penelitian korelasional merupakan penelitian yang bertujuan untuk menemukan ada atau tidaknya hubungan antar variabel, dan apabila ada, seberapa erat hubungan, serta berarti atau tidak hubungan itu. Metode yang digunakan dalam penelitian ini adalah metode survei, dengan teknik pengumpulan data berupa angket dan pengukuran.

Jenis penelitian yang digunakan adalah penelitian deskriptif dengan pendekatan cross sectional. Sampel dalam penelitian ini adalah 45 siswa SMAN 1 Yogyakarta. Variabel yang diteliti yaitu pengetahuan diet, aktivitas fisik dan status gizi. Instrumen yang digunakan untuk mengukur pengetahuan diet adalah dengan tes tingkat pengetahuan yang telah tervalidasi, aktivitas fisik dengan menggunakan Global Physical Activity Questonnaire(GPAQ) dan status gizi dengan indeks massa tubuh. Status gizi digolongkan menjadi status gizi baik dan tidak baik. Pengolahan data dianalisis secara deskriptif. Hubungan pengetahuan diet dan aktivitas fisik terhadap status gizi dengan metode Chi Square dan Goodman Kruskall - Gamma Statistic.

\section{HASIL DAN PEMBAHASAN}

\section{Tingkat Pengetahuan Diet}

Berdasarkan hasil penelitian dari 45 siswa di SMA Negeri 1 Yogyakarta diperoleh deskripsi hasil penelitian untuk data pengetahuan tentang diet yaitu; skor minimum sebesar $=170 ;$ skor maksimum $=224 ;$ mean $=191 ;$ median $=189 ;$ modus $=182$ dan standard deviasi $=$ 12,079. Hasil penelitian pengetahuan tentang diet dapat dideskripsikan sebagai berikut: Tingkat pengetahuan diet siswa SMA Negeri 1 Yogyakarta sebanyak 1 siswa $(2,22 \%)$ dengan kategori sangat rendah 14 siswa $(23,1 \%)$ dengan kategori rendah, 20 orang $(44,44 \%)$ dengan kategori sedang, 6 orang $(13,33 \%)$ dengan kategori tinggi, dan 4 siswa $(8,89 \%)$ memiliki kategori sangat tinggi.

\section{Aktivitas Fisik}

Penelitian ini dimaksudkan untuk mengetahui hubungan antara tingkat pengetahuan diet dan aktivitas fisik terhadap status gizi siswa SMA Negeri 1 Yogyakarta. Pengambilan data tingkat aktivitas fisik pada siswa menggunakan instrumen kuisioner GPAQ yang dilaksanakan di SMAN 1 Yogyakarta. Hasil klasifikasi menjadi tiga skala poin, yaitu: (1) rendah, (2) sedang, (3) tinggi. Hasil analisis statistik deskriptif untuk variabel Tingkat Aktivitas Fisik Siswa SMAN 1Yogyakarta secara keseluruhan dari 45 anak diperoleh rata-rata (mean) $=2266,22$ standart deviasi $=1705,418$. Berdasarkan hasil penelitian tersebut dapat diketahui bahwa tingkat aktivitas fisik siswa SMA Negeri 1 Yogyakarta sebanyak 5 siswa $(11,11 \%)$ dengan kategori rendah, 25 orang $(53,56 \%)$ dengan kategori sedang, dan 15 orang $(33,33 \%)$ dengan kategori tinggi.

\section{Status Gizi}

Penelitian ini dimaksudkan untuk mengetahui hubungan antara pengetahuan diet dan aktivitas fisik terhadap Status Gizi Siswa SMAN 1 Yogyakarta. Pengambilan data status gizi pada siswa menggunakan instrumen IMT/U. Penilaian ini merupakan penilaian status gizi yang dianjurkan untuk anak sekolah di Indonesia. Data Status Gizi Siswa SMAN 1 Yogyakarta digolongkan menjadi lima klasifikasi berdasarkan hasil Z-score. 
Hasil analisis variabel status gizi siswa SMAN 1 Yogyakarta secara keseluruhan dari 45 siswa diperoleh rata-rata (mean) nilai Z-score $=0,03$. Hasil penelitian diketahui dengan jumlah keseluruhan siswa SMAN 1 Yogyakarta terdiri dari 45 siswa tidak ada yang termasuk dalam kategori sangat kurus dan dalam kategori kurus sebanyak 2 anak $(4,44 \%)$, dalam kategori normal sebanyak 33anak (73,33\%), dalam kategori gemuk sebanyak 8 anak $(17,78 \%)$ dan sisanya berkategori obesitas sebanyak 2 anak $(4,44 \%)$.

\section{Pengujian Hipotesis}

Setelah prasyaratan data terpenuhi, langkah selanjutnya melakukan uji hipotesis yang diajukan dalam penelitian ini. Menguji hubungan $\mathrm{X}_{1}$ dan $\mathrm{X}_{2}$ dengan $\mathrm{Y}$ menggunakan uji korelasi chi square dengan software SPSS 25. Analisis data menggunakan metode uji chi square dapat digunakan untuk menguji apakah ada hubungan antara dua variabel kategorik, dengan derajat kepercayaan $95 \%$ dan nilai $\alpha 5 \%$.).

\section{PEMBAHASAN}

\section{Hubungan Tingkat Pengetahuan Diet dengan Status Gizi}

Analisis ini menggunakan pengetahuan diet sebagai variabel independen dan status gizi sebagai variabel dependen untuk diuji korelasi dengan menggunakan uji Chi Square dan Gamma Statistic Dari hasil tersebut dari 4 siswa yang memiliki pengetahuan diet sangat tinggi, 3 siswa memiliki satus gizi yang baik dan 1 siswa memiliki status gizi tidak baik. Dari 6 siswa yang memiliki pengetahuan diet tinggi, 5 siswa memiliki status gizi baik dan 1 siswa memiliki status gizi tidak baik. Siswa yang memiliki tingkat pengetahuan diet sedang terdapat 20 siswa dengan 19 siswa memiliki status gizi baik dan satu siswa memiliki status gizi tidak baik. Selanjutnya, siswa yang memiliki pengetahuan diet rendah dan sangat rendah terdapat 15 siswa dengan 6 siswa memiliki status gizi baik dan 9 siswa dengan status gizi tidak baik.

\section{Hubungan Aktivitas Fisik dengan Status Gizi}

Analisis ini menggunakan aktivitas fisik sebagai variabel independen dan status gizi sebagai variabel dependen untuk diuji korelasi dengan menggunakan uji Chi Square. Analisis korelasi dilakukan untuk mengetahui hubungan antar variabel yang diteliti yaitu pengetahuan diet sebagai variabel independen dan status gizi sebagai variabel dependen dengan menggunakan uji korelasi Chi Square dan gamma statistic Berdasarkan hasil tersebut diketahui bahwa hubungan antara variabel pengetahuan diet terhadap status gizi kuat, signifikan dan searah. Hubungan antara pengetahuan dengan status gizi terlihat bahwa semakin tinggi pengetahuan siswa tentang diet akan semakin besar kemungkinan untuk memiliki status gizi yang baik.

\section{Hubungan Aktivitas Fisik dengan Status Gizi}

Analisis ini menggunakan aktivitas fisik sebagai variabel independen dan status gizi sebagai variabel dependen untuk diuji korelasi dengan menggunakan uji Chi Square. Dari 5 siswa yang memiliki aktivitas fisik rendah, 5 siswa memiliki status gizi tidak baik. Dari 25 siswa yang memiliki aktivitas fisik sedang, 19 siswa memiliki status gizi baik dan 6 siswa memiliki status gizi tidak baik. Dari 15 siswa yang memiliki aktivitas fisik tinggi 14 siswa memiliki status gizi baik dan 1 siswa memiliki status gizi tidak baik. Berdasarkan hasil tersebut diketahui bahwa hubungan antara variabel aktivitas fisik terhadap status gizi kuat. Hubungan antara aktivitas fisik dengan status gizi terlihat bahwa semakin rendah aktivitas fisik siswa maka semakin besar kemungkinan untuk memiliki status gizi tidak baik, sebaliknya jika aktivitas fisik siswa berada dalam kategori sedang dan tinggi kemungkinan memiliki status gizi yang baik.

Berdasarkan hasil penelitian tingkat pengetahuan diet siswa SMAN 1 Yogyakarta, diketahui bahwa siswa dengan kategori tingkat pengetahuan sangat rendah sebanyak 1 siswa, 
rendah 14 siswa, sedang 20 siswa, tinggi 6 siswa dan 4 siswa memiliki tingkat pengetahuan diet dengan kategori sangat tinggi. Dari 4 siswa yang memiliki pengetahuan diet sangat tinggi memiliki status gizi normal. Dari 6 siswa yang memiliki pengetahuan diet tinggi, 4 siswa memiliki status gizi normal dan 2 siswa memiliki status gizi gemuk. Siswa yang memiliki tingkat pengetahuan diet sedang terdapat 20 siswa dengan 19 siswa memiliki status gizi normal dan satu siswa memiliki status gizi gemuk. Selanjutnya, siswa yang memiliki pengetahuan diet rendah dan sangat rendah terdapat 15 siswa dengan 6 siswa memiliki status gizi normal, 2 siswa memiliki status gizi kurus, 4 siswa memiliki status gizi gemuk, dan 2 siswa dengan status gizi obesitas.

Tingkat aktivitas fisik pada siswa SMAN 1 Yogyakarta dari pengisian angket yang dilakukan oleh peneliti mendapatkan hasil 15 siswa $(33,3 \%)$ dalam kategori tinggi, 25 siswa $(55,6 \%)$ dalam kategori sedang dan 5 siswa $(11,1 \%)$ dalam kategori rendah. Hal tersebut menunjukan bahwa aktivitas fisik siswa sebagian besar termasuk dalam kategori sedang. Hasil penelitian menunjukkan mayoritas siswa SMAN 1 Yogyakarta memiliki status gizi normal dengan persentase $73,33, \%$. Namun masih ada mahasiswa yang memiliki status gizi kurus $4,44 \%$, status gizi gemuk $17,78 \%$ dan obesitas $4,44 \%$.

Berdasarkan hasil penelitian ada faktor yang menyebabkan masih adanya siswa dengan kategori status gizi kurus mungkin dikarenakan jumlah asupan zat gizi yang tidak cukup. Hal ini bisa dikarenakan pengaruh lingkungan, remaja anak sekolah ingin memiliki tubuh yang

sempurna dan ideal. Perasaan ini menyebabkan remaja ingin mencoba mengubah tubuhnya dengan memanipulasi diet. Sedangkan faktor yang menyebabkan siswa dengan status gizi lebih dikarenakan terlalu banyak mengkonsumsi karbohidrat, lemak maupun protein, juga karena kurangnya aktivitas fisik. Pola makan merupakan faktor resiko dari kejadian obesitas pada remaja dimana remaja yang memiliki pola makan berlebih mempunyai resiko berat badan lebih dan begitu sebaliknya dengan remaja yang memiliki pola makan kurang dari kebutuhan tubuhnya.

\section{SIMPULAN}

Berdasarkan hasil penelitian tingkat pegetahuan diet dan aktivitas fisik terhadap status gizi siswa SMAN 1 Yogyakarta dapat disimpulkan sebagai berikut : 1) Terdapat hubungan antara tingkat pengetahuan diet dengan status gizi pada Siswa SMAN 1 Yogyakarta. 2) Terdapat hubungan antara aktivitas fisik dengan status gizi pada siswa SMAN 1 Yogyakarta.

\section{DAFTAR PUSTAKA}

Anas Sudijono. (2011). Pengantar statistik pendidikan. Jakarta: Rajawali Pers

Andriyani, Fitria Dwi. (2014). Physical Activity Guidelines for Children. Jurnal Pendidikan Jasmani Indonesia, Volume 10, Nomor 1, April 2014 hal 61-67.

Barasi Mary E. (2007). At a glance ilmu gizi. Terjemahan Hermin Halim. Jakarta: Erlangga.

Clark, Nancy, M.S, RD. 2001. Petunjuk gizi untuk setiap cabang olahraga. Jakarta: PT Raja Grafindo Persada.

Djoko Pekik Irianto. (2007). Panduan gizi lengkap keluarga dan olahraga. Yogyakarta: Andi Offset.

Gibney, Michael J. (2005). Gizi Kesehatan Masyarakat. Jakarta: EGC.

Hidayati, L. 2010. Ragam Jajanan Anak dan Kontribusi Jajanan terhadap Kecukupan Energi dan Zat Gizi Anak Malnutrisi di Lingkungan Kumuh Perkotaan. Makalah pada Seminar Keamanan Produk Pangan Lokal : Mewujudkan Generasi Sehat dan Cerdas. 9 Maret 2010. Surakarta : Prodi Gizi FIK - Universitas Muhammadiyah Surakarta.

Kemenkes RI. (2013). Riset Kesehatan Dasar; RISKESDAS. Jakarta: Balitbang

Mardalena, Ida. (2017). Dasar-dasar Ilmu Gizi Dalam Keperawatan. Yogyakarta: Pustaka Baru Press 
Mubarak, Wahit Iqbal, dkk. 2007. Promosi Kesehatan Sebuah Pengantar Proses Belajar Mangajar dalam Pendidikan. Yogyakarta: Graha Ilmu.

Singh, A. \& Purohit, B. (2011). Evaluation of Global Physical Activity Question (GPAQ) among Healthy and Obese Health Professionals in Central India. Baltic Journal of Health and Physical Activity. 3. Hlm. 34-43

Sugiyono. (2006). Statistika untuk Penelitian. Bandung: Alfabeta.

Suharsimi Arikunto. (2010). Prosedur Penelitian suatu Pendekatan Praktik. Jakarta: PT. Rineka Cipta.

Sulemana, H. Smolensky, M. Lai, D. (2006). Relationship between physical activity and body mass index in adolescents. Medicine \& Science in Sports \& Exercise. 38(6):1182-1186.

Sunita Almatsier. (2001). Prinsip Dasar Ilmu Gizi. Jakarta: PT. Gramedia Pustaka Utama.

Umiyarni, Dyah. (2018) Panduan Gizi dan Kesehatan Anak Sekolah. Yogyakarta: Andi Offset 